\title{
KEMAMPUAN GURU DALAM PENGELOLAAN KELAS DAN HUBUNGANNYA DENGAN MINAT BELAJAR SISWA BIDANG STUDI SEJARAH KEBUDAYAAN ISLAM (SKI) DI MADRASAH TSANAWIYAH (MTs) AN-NUR KOTA CIREBON
}

Anis Khaerunnisa, Iding Wahidin, AkhmadAffandi

Fakultas Ilmu Tarbiyah dan Keguruan Institut Agama Islam Negeri Syekh Nurjati Cirebon

Email : aniesa00@gmail.com

\begin{abstract}
ABSTRAK
Penelitian ini bertolak dari masalah kurangnya minat belajar siswa dalam mengikuti pembelajaran. Sejarah Kebudayaan Islam (SKI), padahal guru telah berusaha mengelola kelas dengan baik, maka seharusnya minat belajar siswa meningkat. Akan tetapi kenyataannya masih ada siswa kurang memiliki minat untuk belajar, sehingga kegiatan pembelajaran menjadi kurang kondusif.

Penelitian ini dilaksanakan dengan tujuan untuk mengetahui pengelolaan kelas, mengetahui minat belajar dan mengetahui hubungan antara pengelolaan kelas dengan minat belajar siswa Madrasah Tsanawiyah (MTs) An-Nur Kota Cirebon pada bidang studi Sejarah Kebudayaan Islam.

Metode yang dilakukan dalam penelitianini, yaitu: observasi, wawancara, angket, dan dokumentasi, sedangkan untuk teknik analisis data yaitu dengan menggunakan analisis variabel untuk mengukur tinggi rendahnya variabel tersebut berdasarkan tabulasi indikator, sedangkan untuk analisis hubungan antar variabel dipergunakan rumus korelasiproductmoment,dankoefisienkorelasi.

Kesimpulan dari penelitian menunjukkan bahwa pelaksanaan pengelolaan kelas sudah dilaksanakan dengan baik dengan skor rata-rata per indikator 3,4. Skor tertinggi diperoleh pada indicator Distribusi Alat dan Bahan Ajar denganskor 3,6, selanjutnya berturut-turut pada indicator Variasi Mengajar dengan skor 3,5, indicator Keluwesan Sikap dengan skor 3,4, indicator Hangat
\end{abstract}


dan Antusias dengan skor 3, 3, dan yang terendah pada indicator Siap dengan Tantangan dan indicator Disiplin dan Berfikir Positif dengan skor 3,2.

Tentang minat belajar siswa pada bidang studi SKI di MTs An-Nur Kota Cirebon diperoleh skor rata-rata sebesar 3,3. Skor tertinggi diperoleh pada indicator Keuletan dan Inisiatif dengan skor 3,5 (tinggi), berturut-turut pada indicator Ketekunen dan Konsentrasi dengan skor 3,45 (Tinggi), indicator Konsisten dan Kerja Keras dengan skor 3,4 (tinggi), indicator Kemauan dengan skor 3,3 (antara tinggi dan rendah), dan yang terendah pada indicator Responsif dengan skor 3,2 (rendah) dan indicator Ketelitian dengan skor 3,2 (rendah).

Diperoleh $r$ hitung sebesar 0,555, sehingga dapat dinyatakan bahwa hubungan antara pengelolaan kelas dengan minat belajar siswa pada bidang studi SKI di Madrasah Tsanawiyah (MTs) An-Nur Kota Cirebon dinyatakan signifikan secara statistik. Artinya semakin berkualitas penerapan pengelolaan kelasakan berhubungan dengan semakin tingginya minat belajar siswa pada bidang studi Sejarah Kebudayaan Islam di Madrasah Tsanawiyah (MTs) An-Nur Kota Cirebon, dan sebaliknya semakin rendah penerapan pengelolaan kelas maka akan berhubungan dengan rendahnya minat belajar siswa. 


\section{PENDAHULUAN}

Tidak ada seseorang pun di dunia ini yang langsung menguasai sesuatu tanpa melalui proses belajar, tidak ada pula sesuatu yang instan. Apapun yang diketahui dan kuasai, semuanya itu berawal dari proses belajar. Pada dasarnya, setiap orang adalah guru, contoh yang digugu dan ditiru, terutama oleh anak yang sering meniru apa yang dilakukan oleh orang-orang sekitarnya yang kemudian menerapkan apa yang mereka lihat, mereka dengar dan mereka rasakan dari lingkungannya. Apa yang telah anak dapatkan ketika masih kecil akan berbekas sangat kuat hingga mereka dewasa. Seperti peribahasa yang kita dengar belajar di waktu kecil bagaikan mengukir di atas batu. Sekolah sebagai salah satu kekuatan besar dalam menciptakan agen perubahan yang perlu ditangani oleh guru-guru yang handal.

Munif Chatib (2009 : 12) mengemukakan bahwa, setiap insan terlahir ke dunia ini dalam keadaan yang berbeda antara satu dengan yang lain. Perbedaan genetik itu juga ditambah dengan pengaruh lingkungan yang melingkupi pengalaman hidup manusia, baik lingkungan keluarga, masyarakat, teman sepermainan, sekolah maupun lingkungan lainnya. Alhasil kombinasi perbedaan genetik dan perbedaan pengalaman hidup tersebut mentransformasi seseorang menjadi individu yang memiliki karakter dasar (membaca, potensi, minat, dan bakat).

Pendidikan di sekolah merupakan lapis kedua setelah keluarga dalam perannya mendidik anak, melalui pendidikan pula, bangsa ini mengembangkan sumber daya manusia yang memiliki rasa percaya diri untuk bersanding dan bersaing dengan bangsa-bangsa lain di dunia. Citra guru dalam pandangan masyarakat semakin hari semakin menurun saja, berbeda dengan spresiasi yang diberikan masyarakat dulu terhadap eksistensi seorang guru. Pandangan umum masyarakat terhadap guru yang ada sekarang menurut Usman (2009 : 2) "bahwa siapapun dapat menjadi guru asalkan ia berpengetahuan”. Pandangan tersebut telah mengusik dan seolah meniadakan pengakuan bahwa guru merupakan pekerja profesi. Layaknya seperti dokter, pilot, arsitektur dan lainnya. Padahal dalam pendidikan, gurulah pemegang kunci yang menjamin kualitas dari pendidikan, di 
samping faktor lainnya seperti sarana prasarana, biaya, kurikulum yang baik, sistem pengelolaan dan pastinya peserta didiknya sendiri.

Upaya pemerintah dalam mewujudkan kualitas dan eksistensi guru sebagai pekerja profesional, mengaturnya dalam penetapan Undang-undang Republik Indoneswia Nomor 1 Tahun 2005 Tentang Guru dan Dosen. Pada pasal 10 ayat 1 Undang-undang itu disebutkan "kompetensi guru sebagaimana dalam pasal 8 meliputi kompetensi paedagogik, kompetensi kepribadian, kompetensi sosial dan kompetensi profesional yang diperoleh melalui pendidikan profesi”.

Kualitas dan kuantitas belajar siswa di dalam kelas bergantung pada banyak faktor, antara lain ialah guru, hubungan antara siswa di dalam kelas. Tujuan umum pengelolaan kelas ialah menyediakan dan menggunakan fasilitas kelas bagi berrmacam-macam kegiatan belajar dan mengajar agar mencapai hasil yang baik. Tujuan khususnya adalah mengembangkan kemampuan siswa dalam menggunakan alat belajar seperti audio visual.

Pengelolaan kelas adalah suatu usaha yang dilakukan oleh penanggungjawab kegiatan belajar mengajar atau yang membantu dengan maksud agar dicapai kondisi optimal sehingga dapat terlaksana kegiatan belajar seperti yang diharapkan (Suharsimi Arikunto, 1992 : 67-68).

Didi Supardie dan Deni Darmawan mengemukakan bahwa keterampilan mengelola kelas adalah kemampuan guru/instruktur untuk menciptakan dan memelihara kondisi belajar yang optimal, dan keterampilan untuk mengembalikan kondisi belajar yang optimal.

Tujuan pengelolaan kelas pada hakikatnya telah terkandung dalam tujuan pendidikan. Secara umum, pengelolaan kelas bertujuan untuk menciptakan suasana kelas yang nyaman untuk tempat berlangsungnya proses belajar mengajar. Dengan demikian, proses tersebut akan dapat berjalan dengan efektif dan terarah, sehingga cita-cita pendidikan dapat tercapai demi terbentuknya sumber daya manusia yang berkualitas.

Minat adalah rasa lebih suka dan rasa keterkaitan pada suatu hal atau aktivitas, tanpa ada yang menyuruh. Minat pada dasarnya adalah penerimaan akan suatu hubungan antara diri sendiri dengan sesuatu di luar diri. Semakin kuat atau dekat hubungan tersebut, semakin besar minatnya. Crow and Crow mengatakan 
bahwa minat berhubungan dengan gaya gerak yang mendorong seseorang untuk menghadapi atau berurusan dengan orang, benda, kegiatan, pengalaman yang dirangsang oleh kegiatan itu sendiri.

Keterampilan mengelola kelas adalah sesuatu yang perlu dimiliki oleh seorang guru mampu mengelola kelas dengan siswa dengan baik, bagaimana seorang guru mampu berinteraksi dengan siswa dengan baik sehingga proses belajar mengajar berjalan efektif dan menyenangkan. Apabila seorang guru mampu mengelola kelas dengan baik, maka minat belajar siswa dalam belajar pun akan meningkat dan memuaskan atau dengan kata lain tujuan pendidikan akan tercapai. Dengan pengelolaan kelas yang baik, maka siswa tidak akan bosan dan jenuh ketika belajar, dengan demikian minat belajar siswa meningkat sehingga mampu mencapai nilai yang memuaskan.

Berdasarkan studi yang penulis lakukan pada bulan Mei 2017 di MTs. AnNur, masalah yang ditemukan penulis adalah kurangnya minat belajar siswa kelas VII, VIII dan IX pada mata pelajaran Sejarah Kebudayaan Islam (SKI), padahal guru SKI di MTs. An-Nur sudah menyampaikan bahan ajar dengan baik dan metode yang dipergunakan juga bervariatif, dan juga sudah menggunakan berbagai alat peraga guna menunjang pencapaian tujuan pembelajaran. Dari hal tersebut terdapat kesenjangan, di satu sisi pihak guru telah berupaya meningkatkan kualitas pembelajaran dengan menggunakan media dan metode sedemikian rupa, namun tetap saja masih kurang berminat dalam mengikuti mata pelajaran Sejarah Kebudayaan Islam.

Berdasarkan latar belakang di atas, peneliti tertarik untuk meneliti lebih dalam mengenai kemampuan guru dalam pengelolaan kelas dan hubungannya dengan minat belajar siswa bidang studi Sejarah Kebudayaan Islam (SKI) MTs. An-Nur Kota Cirebon.

\section{PEMBAHASAN}

Menurut SadirmanN, dkk, pengelolaan kelasa dalah upaya mendayagunakan potensi kelas. (1991:310) Potensi yang dimaksud disini terdiri dari fasilitas yang ada pada kelas ataupun dari siswa dan gurunya dalam menyelenggarakan kegiatan dikelas. Seperti pendapat Haidar Nawawi (1989:115) 
yang menjelaskan bahwa pengelolaan kelas sebagai kemampuan guru dalam mendayagunakan potensi kelas berupa pemberian kesempatan yang seluasluasnya pada setiap personal untuk melakukan kegiatan-kegiatan yang kreatif dan terarah sehingga waktu dan dana dapat dimanfaatkan secara efesien untuk melakukan kegiatan-kegiatan kelas yang berkaitan kurikulum dan perkembangan murid.

Suharsimi Arikunto berpendapat bahwa pengelolaan kelasa dalah suatu usaha yang dilakukan oleh penanggung jawab kegiatan belajar mengajar atau membantu dengan maksud agar dicapai kondisi optimal sehingga dapat terlaksana kegiatan belajar mengajar seperti yang diharapkan (1988:67). Kegiatan pengelolaan yang dimaksud disini adalah guru dapat mendayagunakan fasilitas fisik yang ada disekitar kelas seperti jendela, meja, lampu sesuai dengan fungsi dan dibuat semenarik mungkin sehingga menjadikan kelas dengan kondisi yang nyaman dan optimal.

Menurut Mulyadi (2009:4) pengelolaan kelas adalah seperangkat kegaitan untuk mengembangkan tingkah laku siswa yang diinginkan dan mengurangi atau meniadakan tingkah laku yang tidak diinginkan, mengembangkan hubungan interpersonal dan iklim sosioemosional yang positif serta mengembangkan dan mempertahankan organisasi kelas yang efektif dan produktif.

Pengelolaan itu cakupannya sangat luas sekali, tetapi dapat dirinci dengan bentuk prinsip-prinsip pengelolaan kelas. Karena masalah pengelolaan bukan masalah yang ringan dan bukan pula masalah yang tidak diprioritaskan. Guru dapat mengatasi masalah di dalam kelas dengan mengetahui factor ekstern terkait dengan masalah suasana lingkungan belajar, penempatan siswa, pengelompokkan siswa, jumlah siswa dikelas dan sebagainya, dan factor intern berhubungan dengan masalah emosi, pikiran dan perilaku.

Setiap sekolah ataupun kelas terdapat siswa yang berbeda karakter. Selain itu kondisi kelasnyapun berbeda pula. Sebenarnya terdapat cara walau kondisi kelasnya berbeda-beda. Tergantung dari guru yang mengelola kelas. Untuk memperkecil gangguan dalam pengelolaan kelas maka terapkan prinsipprinsip berikut ini. 
a. Hangat dan Antusias

Untuk menjalin keakraban dengan peserta didik, sehingga peserta didik semakin antusias dan aktif saat proses pembelajaran berlangsung.

b. Tantangan

Penggunaan kata-kata, tindakan, cara kerja, atau bahan-bahan yang menantang akan meningkatkan gairah anak didik dan akan menarik perhatian anak didik dan dapat mengembalikan gairah belajar mereka.

c. Bervariasi

Penggunaan variasi metode,alat,media dan gaya belajar guru akan menghindari kejenuhan peserta didik dan akan membuat peserta didik termotivasi.

d. Keluwesan

Guru yang memiliki sikap luwes akan bijak dalam menggunakan strategi pembelajaran, karena guru akan menyesuaikan strategi pembelajaran dengan situasi kondisi kelasdan siswa.

e. Penekanan padahal-hal yang positif

Penekanan yang dilakukan guru terhadap tingkah laku anak didik yang positif daripada mengomentari tingkah laku yang negatif.

f. Penanaman disiplin diri

Guru sebaiknya selalu mendorong anak didik untuk melaksanakan disiplin diri sendiri dan guru sendiri hendaknya menjadi teladan mengenai pengendalian diri dan pelaksanaan tanggung jawab. (Djamarah dan Aswan. 2002: 206).

Minat adalah suatu perangkat mental yang terdiri dari suatu campuran dari perasaan, harapan, pendirian, prasangka, rasa takut, atau kecenderungankecenderungan lain yang mengarahkan individu kepada suatu pilihan tertentu. Minat merupakan salah satu faktor yang dapat mempengaruhi usaha yang dilakukan seseorang. Minat yang kuat akan menimbulkan usaha yang gigih, serius dan tidak mudah putus asa dalam menghadapi tantangan.

Minat tidak dibawa sejak lahir, melainkan diperoleh kemudian. Minat terhadap sesuatu dipelajari dan mempengaruhi belajar selanjutnya serta mempengaruhi penerimaan minat-minat baru. Jadi, minat terhadap sesuatu 
merupakan hasil belajar dan menyokong belajar selanjutnya. Walaupun minat terhadap sesuatu hal tidak merupakan hal yang hakiki untuk dapat mempelajari hal tersebut, asumsi umum menyatakan bahwa minat akan membantu seseorang mempelajarinya. (Slameto, 2013: 180).

Minat berkaitan erat dengan motivasi. Motivasi dapat dikatakan serangkaian usaha untuk menyediakan kondisi-kondisi tertentu, sehingga seseorang itu mau dan ingin melakukan sesuatu, dan bila ia tidak suka, maka akan berusaha untuk meniadakan atau mengelakkan perasaan tidak suka itu. Begitu juga minat dapat diartikan sebagai suatu kondisi yang terjadi apabila seseorang melihat ciri-ciri atau arti sementara situasi yang dihubungkan dengan keinginankeinginan atau kebutuhan-kebutuhannya sendiri. (Sadirman, 1992: 75).

Berdasarkan uraian di atas dapat disimpulkan bahwa peranan kepribadian guru berperan penting dalam proses belajar mengajar. Peranan kepribadian guru lebih kepada aspek sikapnya. Membimbing dan mencotohkan kepada siswa bagaimana cara berperilaku yang baik, berpenampilan yang rapih, membiasakan diri untuk disiplin, menjadi pribadi yang lebih baik lagi. Kepribadian guru akan menjadi tolok ukur siswa untuk menjadi individu yang berakhlak mulia.

\section{Tempat dan Waktu Penelitian}

\section{Tempat Penelitian}

Penelitian ini dilakukan di MTs An-Nur Kota Cirebon pada semester genap tahun pelajaran 2016/2017 yang terletak di Kelurahan Jagasatru Kecamatan Pekalipan Kota Cirebon.

\section{Waktu Penelitian}

Penelitian ini dilaksanakan pada tanggal 1 April s/d 30 Juni 2017 semester genap tahun pelajaran 2016/2017 antara bulan April-Juni 2016.

MTs AN-NUR Kota Cirebon mempunyai tugas pokok yaitu mendidik dan mengajarkan kepada para peserta didik agar memperoleh ilmu agama dan ilmu pengetahuan yang dapat bermanfaat untuk dirinya, keluarga dan masyarakat kemudian agar menerapkannya dalam kehidupan sehari-hari.

MTs AN-NURKota Cirebon adalah sebuah lembaga independen yang memiliki motivasi dan tujuan ikut berpartisipasi dalam mengisi kemerdekan 
NKRI yaitu melalui sebuah lembaga pendidikan, sehingga dalam berkiprah dalam turut serta mencerdaskan kehidupan bangsa serta dapat menciptakan lapangan kerja baru bagi para lulusan S1 yang belum mendapatkan kesempatan kerja baik dalam linkungan kedinasan pemerintah aatupun swasta. Dan madrasah ini dibangun atas dasar silaturahim kekeluargaan yaitu, menutamakan pendidikan moral, spiritual dan peraturan pendidikan, perundang-undangan pendidikan yang berlaku.

Saat ini MTs AN-NURKota Cirebon memperoleh status "Terakreditasi A” Tahun 2011 dengan Nomor Statistik Madrasah (NSM) 121232740005 dan NPSN 20222539

\section{Sumber dan Jenis Data}

\section{Sumber Data}

Dalam penelitian ini penulis menggunakandua sumber data teoritis dan data empirik.Data teoritis penulis mengambil dari buku-buku yang relevan dengan masalah yang diteliti. Sedangkan sumber empirik dalam penelitian ini adalah siswa kelas VIII AMTs AN-NURKota Cirebon, serta mengambil dari berbagai sumber yang dianggap mampu memberikan data secara objektif yang ada di lapangan.

\section{Jenis Data}

Data dapat dibedakan berdasarkan jenis dan sumbernya. Menurut Azwar (1999:91), dan Subagyo (1997:87), mengatakan bahwa menurut sumbernya data penelitian ada dua yaitu data primer dan data sekunder, sedangkan atas dasar jenis data ada data kualitatif dan kuantitatif. Data primer adalah data yang diperoleh langsung dari subjek penelitian sebagai sumber informasi dengan menggunakan alat pengukuran atau alat pengambilan data. Sedangkan data sekunder adalah data yang diperoleh dari sumber lain, tidak langsung diperoleh dari subjek penelitian. Data kualitatif yaitu berupa kategori-kategori, sedangkan data kuantitatif berupa angka-angka. Data primer dan data sekunder dapat digolongkan menurut jenisnya sebagai data kualitatif dan data kuantitatif tergantung bagaimana cara memperoleh data tersebut.

Penelitian ini menggunakan jenis data primer kuantitatif.Data kuantitatif berdasarkan jenis data yang berupa angka atau jumlah tertentu atau hasil 
kuantifikasi dari data kualitatif, yaitu kemampuan pengelolaan kelas guru bidang studi Sejarah Kebudayaan Islam dan minat belajar siswa MTS AN NUR Kota Cirebon pada bidang studi Sejarah Kebudayaan Islam.

\section{Populasi dan Sampel}

\section{Populasi}

Populasi menurut Sugiyono (2015:117) adalah wilayah generalisasi yang terdiri atas obyek/ subyek yang mempunyai kualitas dan karakteristik tertentu yang ditetapkan oleh peneliti untuk dipelajari dan kemudian ditarik kesimpulannya. Populasi dalam penelitian ini adalah seluruh siswa kelas VII, VIII dan IXMTs AN-NURKota Cirebon sebanyak 316 siswa, terdiri dari lakiLaki 138 dan siswa perempuan sebanyak 178. Jumlah tersebut tersebar pada kelas VII sebanyak 109 orang, kelas VIII sebanyak 102 orang dan kelas IX sebanyak 97 orang.

\section{Sampel}

Pada penelitian ini penulis mengambil teknik pengambilan data dengan caracluster sampling yang dimana mengacu pada kelompok bukan individu. Dalam penelitian ini cluster sampling digunakan untuk memilih tingkatan kelas yang direkomendasi oleh pihak madrasah, yaitu kelas VIII. Jumlah kelas VIII pada tahun ajaran 2016/2017 sebanyak 3 rombongan belajar, sehingga untuk menentukan kelas yang dipilih ditentukan secara acak (random sampling) dan hasilnya adalah kelas VIII C yang berjumlah 30 orang.

\section{Variabel Penelitian}

Sugiyono (2009:60) menyatakan bahwa: "variabel penelitian pada dasarnya adalah segala sesuatu yang berbentuk apa saja yang ditetapkan oleh peneliti untuk dipelajari sehingga diperoleh informasi tentang hal tersebut, kemudian ditarik kesimpulannya”. Menurut Hadi (2000:4), variabel dinyatakan sebagai objek atau komponen dalam penelitian yang akan diteliti. Senada dengan itu Ari Kunto (2006:126) menyatakan bahwa: variabel adalah gejala yang bervariasi, yang menjadi objek penelitian.

1. Variabel Independen (variabel bebas) 
Sugiyono (2015: 61) Variabel independen (variabel bebas) merupakan variabel yang mempengaruhi atau yang menjadi sebab atau timbulnya variabel dependen (terikat).Variabel bebas dalam penelitian ini adalah kemampuan pengelolaan pengajaran guru Sejarah Kebudayaan IslamMTs AN-NURKota Cirebon.

2. Variabel Dependen (variabel terikat)

Sugiyono (2015: 61) menyatakan bahwa variabel dependen (variabel terikat) merupakan variabel yang dipengaruhi atau yang menjadi akibat, karena adanya variabel bebas.Variabel terikat dalam penelitian ini adalah minat belajar siswa pada bidang studi Sejarah Kebudayaan Islam.

3. Desain penelitian

Desain penelitian yang digunakan dalam penelitian ini adalah penelitian korelasional (Correlational Research).Menurut Sudijono (2014:179) penelitian koresional adalah penelitian yang akan melihat hubungan antara dua variabel atau lebih. Pada penelitian ini akan melihat hubungan antara dua variabel, yaitu kemampuan pengelolaan pengajaran guru Sejarah Kebudayaan Islam dengan minat belajar siswa pada bidang studi Sejarah Kebudayaan Islam kelas VII, VIII dan IX MTs AN-NURKota Cirebon.

\section{Instrumen Penelitian}

Sugiyono (2015:148) mengemukakan bahwa instrumen penelitian adalah suatu alat yang digunakan mengukur fenomena alam maupun sosial yang diamati.Secara spesifik semua fenomena ini disebut variabel penelitian. Instrumen yang digunakan dalam penelitian ini adalah lembar angket, lembar observasi cara mengajar guru dan cara belajar siswa, lembar wawancara, dan dokumentasi.

Instrumen utama dalam penelitian ini menggunakan angket dan instrumen pendukung yang dipergunakan adalah observasi, wawancara dan studi dokumentasi.

Jenis angket yang digunakan dalam penelitian ini yaitu angket tertutup yang diberikan kepada siswa yang dijadikan sampel penelitian sebanyak 30 oranguntuk mengetahui kemampuan pengelolaan pengajaran guru Sejarah Kebudayaan Islamdan minat belajar siswa pada bidang studi Sejarah Kebudayaan Islam. 


\section{Teknik Pengumpulan Data}

Untuk memperoleh data dan informasi yang berkaitan dengan masalah yang dikaji, telah ditempuh pengumpulan data dengan berbagai cara yaitu melalui observasi, wawancara, angket, dan dokumentasi. Keempat instrumen tersebut dapat diuraikan sebagai berikut:

1. Observasi

Observasi adalah pengamatan langsung ke lokasi yang diteliti yaitu MTs AN-NURKota Cirebon, bertujuan untuk memperoleh data yang berkaitan dengan proses mengamati dan mencatat secara sistematis mengenai tingkah laku guru yang sedang melaksanakan kegiatan pembelajaran. dan mencatat mengenai tingkah laku siswa yang sedang mengikuti kegiatan pembelajaran. Observasi yang dilakukan tanpa mengganggu kegiatan mengajar guru yang sedang diamati, dengan menggunakan pedoman pengamatan yang telah disiapkan.Adapun pihak yang yang dihubungi adalah Kepala Sekolah, Guru mata pelajaran Sejarah Kebudayaan Islam, dan siswasiswi MTs AN-NURKota Cirebon.

2. Wawancara (interview)

Wawancara merupakan suatu teknik pengumpulan data yang dilakukan secara lisan dalam pertemuan tatap muka secara individual dengan tujuan untuk memperoleh informasi yang dibutuhkan oleh peneliti.Teknik ini mendasarkan diri pada laporan tentang diri sendiri atau self report atau setidak-tidaknya pada pengetahuan dan atau keyakinan pribadi.Teknik wawancara dilakukan dengan mengadakan Tanya jawab langsung dengan nara sumber yakni: Guru mata pelajaran Sejarah Kebudayaan Islam, dan Siswa kelas VII, VIII dan IX.

3. Angket

Teknik ini penulis gunakan untuk memperoleh data tentang kemampuan pengelolaan pengajaran guru Sejarah Kebudayaan Islam dan minat belajar siswa pada bidang studi Sejarah Kebudayaan Islam, “ angket merupakan suatu alat pengumpul data, berisi pertanyaan secara tertulis yang ditunjukan kepada subjek (responden) penelitian. Pertanyaan-pertanyaan bisa berbentuk 
tettutup (berstruktur), dan bisa juga berbentuk terbuka (tak berstruktur)". (Faisal,1999: 1222).

Angket merupakan suatu teknik atau cara pengumpulan data secara tidak langsung. Instrumen angket berisi sejumlah pertanyaan pertanyaan yang harus dijawab oleh responden (Sukmadinata, 2005:219). Sedangkan menurut Ridwan (2010:52-53) angket adalah daftar pertanyaan yang diberikan kepada orang lain yang bersedia memberikan respon sesuai permintaan pengguna.

Peneliti memberikan angket kepada siswa berkaitan dengan kemampuan pengelolaan pengajaran guru Sejarah Kebudayaan Islam dan minat belajar siswa pada bidang studi Sejarah Kebudayaan Islam, setelah itu penulis menyimpulkan hasil dari angket yang telah diisi oleh siswa. Dalam penelitian ini angket yang digunakan adalah skala likert dengan limaoption, yaitu sangat setuju, setuju, netral, tidak setuju, dan sangat tidak setuju.

Skala likert adalah suatu skala psikometrik yang umum digunakan dalam kuesioner, dan merupakan skala paling banyak digunakan dalam riset berupa survey. Nama skala ini diambil dari nama rinses likert, yang menerbitkan suatu laporan yang menjelaskan penggunaannya (Rensis likert, 1932:140)

Penelitian menggunakan teknik angket didasarkan pada keuntungannya, yaitu mendapatkan data yang cukup banyak dan tersebar merata, sebagaimana dijelaskan bahwa, " Daftar kuesioner juga dapat dijawab secara tertulis oleh informan atau disebut angket. Angket mempunyai keuntungan antara lain yaitu secara kualitatif peneliti dapat memperoleh data yang cukup banyak, yang tersebar secara merata dalam wilayah yang akan diselidiki” (Keraf, 1980: 161).

Berdasarkan pendapat diatas, maka untuk kepentingan penelitian ini, penulis menggunakan bentuk angket sebagai alat pengumpul data. Bentuk angket yang digunakan dalam bentuk angket tertutup untuk kemampuan pengelolaan pengajaran guru Sejarah Kebudayaan Islam (Variabel X) dan angket terbuka untuk minat belajar siswa pada bidang studi Sejarah Kebudayaan Islam(Variabel Y), yaitu angket yang alternatif jawabannya teah disediadakan sehingga responden (siswa) hanya memilih jawaban yang dianggap cocok atau sesuai dengan keadaan data. 
4. Dokumentasi

Studi dokumentasi merupakan mengumpulkan data dengan melihat, mencatat, menghimpun dan menganalisis dokumen-dokumen yang sudah tersedia, baik dokumen tertulis seperti arsip termasuk juga buku tentang teori, pendapat, dalil, atau hukum, dan hal lainnya yang berhubungan dengan masalah penelitian. Metode ini dilakukan dengan melihat dokumen-dokumen resmi, catatan-catata serta buku-buku peraturan yang ada.

Dalam penelitian ini, dokumentasi digunakan untuk memperoleh data mengenai beberapa kemampuan pengelolaan pengajaran guru Sejarah Kebudayaan Islam seperti penyusunan rencana pelaksanaan pembelajaran (RPP) dan dokumentasi dalam penelitian ini adalah dengan cara mencatat minat belajar siswa pada bidang studi Sejarah Kebudayaan Islam seperi nilai prestasi ujian tengah semester, ulangan harian siswa, dan pekerjaan rumah (PR) pada mata pelajaran Sejarah Kebudayaan Islam pada kegiatan pembelajaran pada semester ganjil di MTs AN-NURKota Cirebon.

\section{Teknik Analisis Data}

Setelah data diperoleh, selanjutnya dilakukan analisis terhadap data tersebut. Adapun analisis yang digunakan dengan penelitian ini meliputi:

1. Analisis variabel (variabel $\mathrm{X}$ dan $\mathrm{Y}$ ), berpatokan pada Suharsimi Arikunto (2006 : 153) yaitu menghitung skor rata-rata masing-masing indikator kemudian membandingkan dengan skor masing-masing item pertanyaan dengan kategori sebagai berikut :

a. Nilai item yang berada di atas rata-rata indikator/sub-indikator menunjukkan kategori tinggi, disingkat $\mathrm{T}$.

b. Nilai item yang berada di bawah rata-rata indikator menunjukklan kategori rendah, disingkat $\mathrm{R}$.

2. Untuk mengetahui korelasi antara variabel $\mathrm{X}$ dan variabel $\mathrm{Y}$, penulis menggunakan rumus product moment sebagai berikut:

$$
r_{x y}=\frac{\mathrm{N} \Sigma \mathrm{xy}-(\Sigma \mathrm{x})(\Sigma \mathrm{y})}{\sqrt{\left\{\mathrm{N} \Sigma \mathrm{x}^{2}-(\Sigma \mathrm{x})^{2}\right\}\left\{\mathrm{N} \Sigma \mathrm{y}^{2}-(\Sigma \mathrm{y})^{2}\right\}}}
$$

\section{Keterangan:}

$$
\begin{aligned}
& r_{x y}: \text { koefisien korelasi " } \mathrm{r} \text { " antara } \mathrm{x} \text { dan } \mathrm{y} \\
& \mathrm{x}
\end{aligned}
$$




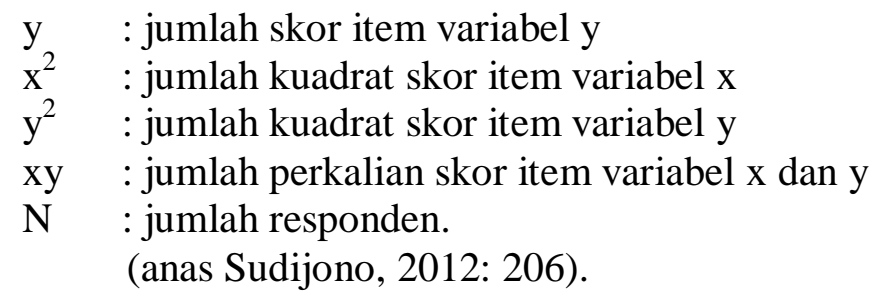

\section{Pengelolaan Kelas di MTs. An-Nur Kota Cirebon}

Berikut dalam penelitian ini, peneliti menyebarkan angket sebanyak responden yang diambil yaitu 35 siswa di MTs. An-Nur Kota Cirebon. Adapun jumlah angket yang peneliti bagikan sebanyak 20 pernyataan. Setiap pernyataan tersebut terdapat alternative jawaban yang bersifat positif dengan ketentuan sebagai berikut :

1. Pernyataan positif Selalu skornya adalah 4

2. Sering skornya adalah 3

3. Kadang-kadang skornya adalah 2

4. Tidak pernah skornyaadalah 1 .

\section{Minat Belajar Pada Bidang Studi SKI di Madrasah Tsanawiyah (MTs) An Nur Kota Cirebon}

Skor yang digunakan dengan penyusunan motivasi belajar siswa Madrasah Tsanawiyah (MTs) An-nur Kota Cirebon penulis menggunakan indikator motivasi belajar, indikator motivasi belajar indikator kemauan, responsiv, ketekunan, konsentrasi, ketelitian, keuletan, inisiatif, konsisten dan kerja keras.

\section{Hubungan Pengelolaan Kelas dengan Minat Belajar Siswa pada Bidang Studi SKI}

Untuk mengetahui ada tidaknya hubungan tes formatifsebagai variabel (x) dengan motivasi belajar sebagai variabel (y), maka penulis sajikan kedua data variabel yang diperoleh dari hasil angket terhadap 30 siswa sebagai responden. Kemudian akan dikorelasikan dengan menggunakan rumus korelasi product moment.

Sebelum mengetahui adakah hubungan pengelolaan kelas dengan minat belajar siswa pada mata pelajaran SKI di MTs An-Nur Kota Cirebon, maka 
penulis perlu mengetahui besarnya hubunganpengelolaan kelas dengan minat belajar pada mata pelajaran SKI di kalangan siswa Madrasah Tsanawiyah (MTs) An-Nur Kota Cirebondapat diperoleh dengan menggunakan rumus korelasi product moment sebagai berikut:

$$
\begin{aligned}
& r_{x y}=\frac{N \sum x y-\left(\sum x\right)\left(\sum y\right)}{\sqrt{\left.\left\{N \sum x^{2}-\left(\sum x\right)^{2}\right\} N \sum y^{2}-\left(\sum y\right)^{2}\right\}}} \\
& =\frac{30.122482-(1906)(1952)}{\sqrt{\left\{30 \sum 122482-(1906)^{2}\right\}\left\{30 \sum 127814-(1952)^{2}\right\}}} \\
& =\frac{3.720 .690-3.720 .512}{\sqrt{\sqrt{\{3.674 .460-3.632 .836\}\{3.834 .420-3.810 .304\}}}} \\
& =\frac{178}{\sqrt{(40.624)(24.116)}} \\
& =\frac{178}{31.299} \\
& =0.555
\end{aligned}
$$

Dengan diperoleh $r$ hitung sebesar 0,555 maka dapat dikonsultasikan pada indeks korelasi product moment pada buku Anas Sudjiono (2012: 193) sebagai berikut:

Tabel 1. Angka Indeks Korelasi "r" Product Moment (rxy)

\begin{tabular}{|c|l|}
\hline $\begin{array}{c}\text { Besarnya "r" product } \\
\text { moment }(\text { rxy })\end{array}$ & \multicolumn{1}{c|}{ Interprestasi } \\
\hline $0,90-1,00$ & $\begin{array}{l}\text { Antara variabel x dan variabel y } \\
\text { terdapat korelasi yang sangat kuat/ } \\
\text { tinggi }\end{array}$ \\
\hline $0,70-0,90$ & $\begin{array}{l}\text { Antara variabel x dan variabel y } \\
\text { terdapat korelasi yang kuat / tinggi }\end{array}$ \\
\hline $0,40-0,70$ & $\begin{array}{l}\text { Antara variabel x dan variabel y } \\
\text { terdapat korelasi yang sedang atau } \\
\text { cukup }\end{array}$ \\
\hline $0,20-0,40$ & $\begin{array}{l}\text { Antara variabel x dan variabel y } \\
\text { terdapat korelasi yang lemah atau } \\
\text { rendah }\end{array}$ \\
\hline $0,00-0,20$ & $\begin{array}{l}\text { Antara variabel x dan variabel y } \\
\text { memang terdapat korelasi, akan } \\
\text { tetapi itu sangat lemah / sangat } \\
\text { rendah }\end{array}$ \\
\hline
\end{tabular}

Anas Sudjiono (2012: 193) 
Berdasarkan hasil perhitungan diatas, diperoleh nilai koefisien antara penerapan tes formatif terhadap motivasi belajar siswa pada pembelajaran Fikih sebesar $r_{x y}=0,55$. Hasil tersebut apabila dirubah kedalam skala konservati, 0,55 berada pada interval 0,40-0,70 yang berarti memiliki tingkat korelasi yang sedang atau cukup. Sehingga kita dapat menginterpretasikan yaitu terdapat hubungan antara pengaruh tes formatif dalam meningkatkan motivasi belajar siswa pada mata pelajaran SKI Madrasah Tsanawiyah (MTs) An-Nur Kota Cirebon.

Nilai korelasi dari hasil perhitungan diatas, selanjutnya dihitung nilai koefisien determinasinya, untuk mengetahui apakah ada pengaruh antara pengelolaan kelas (variabel $\mathrm{x}$ ) dengan minat belajar siswa pada pembelajaran SKI (variabel y), rumusnya sebagai berikut :

$$
\begin{aligned}
\mathrm{KD} & =\mathrm{r}^{2} \times 100 \% \\
& =0,555^{2} \times 100 \% \\
& =0,308022 \times 100 \% \\
& =30,80 \%
\end{aligned}
$$

Hasil dari koefisien determinasi di atas, menunjukan bahwa pengaruh tes formatif unuk meningkatkan motivasi belajar siswa pada pembelajaran SKI di Madrasah Tsanawiyah (MTs) An-Nur Kota Cirebon30,80 \%.Dan 69,20\% berhubungan dengan faktor lain, misalnya faktor lingkungan, keluaarga, IQ dan sebagainya yang berpengaruh terhadap motivasi belajar siswa.

\section{Uji Hipotesis}

Penelitian ini menggunakan hipotesisi sebagai berikut:

Ha :Adanya hubungan Pengelolaan Kelas dengan Minat Belajar Siswa pada bidang studi SKI di Madrasah Tsanawiyah An-Nur Kota Cirebon.

Ho :Tidak adahubungan Pengelolaan Kelas dengan Minat Belajar Siswa pada bidang studi SKI di Madrasah Tsanawiyah An-Nur Kota Cirebon.

Berdasarkan perhitungan " $r$ " product moment dihasilkan nilai $r$ sebesar 0,555 kemudian $r$ hitung di atas konsultasikan ke $r$ tabel pada sample sebesar 30 diperoleh $r$ tabel sebesar 0,361. Dengan begitu dapat dikatakan bahwa $r$ hitung berada di atas $\mathrm{r}$ tabel, maka uji hipotesis menjawab $\mathrm{H}_{\mathrm{a}}$ diterimadan $\mathrm{H}_{\mathrm{o}}$ ditolak. Artinya bahwa antara variable X (Pengelolaan Kelas) dengan variabel Y (Minat 
Belajar) siswa pada pelajaran SKI Madrasah Tsanawiyah (MTs) An-Nur Kota Cirebonterdapat hubungan yang signifikan secara statistic.

Artinya semakin berkualitas penerapan pengelolaan kelas akan berhubungan dengan semakin tingginya minat belajar siswa pada bidang studi Sejarah Kebudayaan Islam di Madrasah Tsanawiyah (MTs) An-Nur Kota Cirebon, dan sebaliknya semakin rendah penerapan pengelolaan kelas maka akan berhubungan dengan rendahnya minat belajar siswa.

\section{Kesimpulan}

Berdasarkan penelitian dan pembahasan penelitian, maka peneliti dapat mengambil beberapa kesimpulan yaitu sebagai berikut:

1. Hasil penelitian menunjukkan bahwa pelaksanaan pengelolaan kelas sudah dilaksanakan dengan baik dengan skor rata-rata per indikator 3,4. Skor tertinggi diperoleh pada indikator Distribusi Alat dan Bahan Ajar dengan skor 3,6, selanjutnya berturut-turut pada indikator Variasi Mengajar dengan skor 3,5, indikator Keluwesan Sikap dengan skor 3,4, indikator Hangat dan Antusias dengan skor 3,3, dan yang terendah pada indikator Siap dengan Tantangan dan indikator Disiplin dan Berfikir Positif dengan skor 3,2

2. Hasil analisis data tentang minat belajar siswa pada bidang studi SKI di MTs An-Nur Kota Cirebon diperoleh skor rata-rata sebesar 3,3. Skor tertinggi diperoleh pada indikator Keuletan dan Inisiatif dengan skor 3,5 (tinggi), berturut-turut pada indikator Ketekunen dan Konsentrasi dengan skor 3,45 (Tinggi), indikator Konsisten dan Kerja Keras dengan skor 3,4 (tinggi), indikator Kemauan dengan skor 3,3 (antara tinggi dan rendah), dan yang terendah pada indikator Responsif dengan skor 3,2 (rendah) dan indikator Ketelitian dengan skor 3,2 (rendah).

3. Dengan diperoleh $r$ hitung sebesar 0,555 dapat dinyatakan bahwa hubungan antara pengelolaan kelas dengan minat belajar siswa pada bidang studi SKI di Madrasah Tsanawiyah (MTs) An-Nur Kota Cirebon dinyatakan signifikan secara statistik. Artinya semakin berkualitas penerapan pengelolaan kelas akan berhubungan dengan semakin tingginya minat belajar siswa pada bidang studi Sejarah Kebudayaan Islam di Madrasah Tsanawiyah (MTs) An-Nur 
Kota Cirebon, dan sebaliknya semakin rendah penerapan pengelolaan kelas maka akan berhubungan dengan rendahnya minat belajar siswa.

\section{DAFTAR PUSTAKA}

Arikunto, Suharsimi. 1988. Pengelolaan Kelas dan Siswa. Jakarta: Rajawali. . 2010. Prosedur Penelitian Suatu Pendekatan Praktik.

Jakarta: Rineka Cipta.

Asmani, Jamal Ma'mur. 2004. 7 Kompetensi Guru Menyenangkan dan Profesional. Jogjakarta: Power Books (IHDINA). 2015. Tips Menjadi Guru Inspiratif, Kreatif dan Inovatif. Jogjakarta : Diva Press.

Dalyono, M. 1997. Psikologi Pendidikan. Jakarta: Rineka Cipta.

Danim, Sudarwan dan Yunan Danim. 2011. Administrasi Sekolah dan Manajemen Kelas. Bandung : Pustaka Setia.

Departemen Agama RI. 2005. Mushaf Al-Qur'an Terjemah Edisi Tahun 2002.Jakarta: Al Huda.

Djamarah, Syaiful Bahri dan Aswan Zain. 2002. Strategi Belajar Mengajar. Jakarta: Rineka Cipta.

.2014. Guru \& Anak Didik dalam interaksi edukatif. Jakarta: Rineka Cipta).

Hamid, Sholeh. 2014. Metode Edutainment (Menjadikan Siswa Kreatif dan Nyaman di Kelas). Yogyakarta : Diva Press.

Hamalik, Oemar. 2009. Psikologi Belajar dan Mengajar. Bandung: Sinar Baru Algensindo.

Imam, Azhar. 2013. Pengelolaan Kelas dari Teori ke Praktek. Yogyakarta : Insyira.

Khairani, Makmun. 2017. Psikologi Belajar. Yogyakarta: Aswaja Pressindo.

Mujatahid. 2011. Pengembangan Profesi Guru. Malang: UIN-Maliki Press.

Mulyadi. 2009. Classroom Management. Malang : UIN Malang Press. 
Mulyasa. 2008. Standar Kompetensi dan Sertifikasi Guru. Bandung: PT Remaja Rosdakarya.

Nawawi, Hadair. 1989. Organisasi Sekolah dan Pengelolaan Kelas sebagai Lembaga Pendidikan. Jakarta : Haji Masagung.

Purwanto, Ngalim. 2004. Psikologi Pendidikan. Bandung: Remaja Rosdakarya.

Purwanto, Yadi. 2007. Psikologi Kepibadian. Bandung: PT Refika Aditama.

Sagala, Saiful. 2009. Kemampuan Profesional Guru dan Tenaga Kependidikan. Bandung: Alfabeta.

Sanjaya, Wina. 2016. Strategi Pembelajaran : Berorientasi Standar Proses Pendidikan. Jakarta : Kencana.

Satori, Djam'an. 2005. Profesi Keguruan. Jakarta: Universitas Terbuka.

Slameto, 2003. Belajar dan Faktor-Faktor yang Mempengaruhinya. Jakarta: Rineka Cipta.

Subroto,Suryo. 1997. Proses Belajar Mengajar. Jakarta: PT Rineka Cipta.

Sudaryono, 2012, Dasar-Dasar Evaluasi Pembelajaran. Yogyakarta: Graha Ilmu.

Sugiyono, 2011. Metode Penelitian Pendidikan. Alfabeta.: Bandung.

Sujanto, Agus. 1997. Psikologi Kepribadian. Jakarta: Bumi Aksara.

Surya, Mohamad. 2004. Psikologi Pembelajaran dan Pengajaran. Bandung: Pustaka Bani Quraisy. 